\title{
DE KAMER DER WEST-INDISCHE COMPAGNIE TE DELFT.
}

\author{
DOOR
}

Dr. C. TE LINTUM.

De titel boven dit opstel zal menigeen verbazen. Inmers, onze gewone school- en haudboeken der geschiedenis hebben jaren lang verkondigd, dat de West-Indische Compagnie slechts vijf kamers heeft bezeten, namelijk die van Amsterdam, van 'Zeeland, van de Maas, van het Noorder-Kwartier en van Groningen, welker kantoren gevestigd waren in Amsterdam, Middelburg, Rotterdam, Hoorn en Groningen. Ja, een standaardwerk op het gebied van den Indischen handel, van Rees' "Geschiedenis der Staathuishoudkuude in Nederland" heeft geen andere afdeelingen genoemd dan deze, 't geen trouwens wel de geheime oorzaak van de bedoelde tekortkoming der leerboeken zal wezen. De Vaderlandsche Geschiedenis van Dr. J. A. Wijune, die jaren lang gegolden heeft als het vademecum voor onderwijzers en leerlingen, bant zelfs Delft nog nadrukkelijker weg uit de sfeer van den West-Iudischen handel dan de anderen, want, terwijl zij in Zeeland, het Noorderkwartier en Groningen geen bepaalde stad als zetel aanwijst, voegt zij achter de Kamer van de Maze de uitlegging "d.i. Rotterdam."

Joannes De Laet, die in 1644 zijne bekende "Historie ofte jaerlyx verhael van de verrichtingen der Grootmogende West-Indische Compagnie" uitgaf, heeft zich om de juiste plaats der Kamers weinig bekommerd, aangezien 't hem alleen te doen was, om de verdiensten der Compagnie op den Oceaan en elders zoo sterk mogelijk in 't licht te stellen, opdat haar octrooi niet zou ingetrokken worden; hij geeft voor de Kamers niets anders dan eene lijst van bewindhebbers tot het jaar 1636 ; daarbij nu prijkt de Kamer van de Maze wel is waar met negen en twintig namen, tien voor Dordt, tien voor Delft en negen voor Rotterdam, maar er blijkt volstrekt niet uit, dat deze drie steden ieder een eigen kantoor be- 
zaten: integendeel, wie de lijst ziet, moet eerder denken, dat er één kantoor aan de Maas bestond (b.v. te Rotterdam) en dat de directeuren daarvan benoemd werden en woonachtig waren in Dordt, Delft en Rotterlam.

Franklin Jameson eindelijk, die in onze dagen de treffende geschiedenis van Willem Usselinx beschreven heeft en daarbij natuurlijk ook nog eens de West-Indische Compaguie, asschepoester bij de historici, is gaan bestudeeren, spreekt niet anders dan terloops over "the cities on the Maas", 1 die eene Kamer zouden krijgen volgens Usselinx' plan van 1606 , 't geen dus geheel in 't midden laat, of bij de werkelijke oprichting, vijftien jaar later, deze Maassteden ééne Kamer verkregen hebben dau wel twee of drie of nog meer.

Zoo is dan, mag men wel zeggen, alles gedaan, om op het gebied van den West-Indischen handel het aandeel van Delft, zoowel als dat van Dordt, in 't vergeetboek te brengen, wat maar al te goed gelukt is. Alleen de trouwe stadsbeschrijvers, die in de $17^{\mathrm{e}}$ en $18^{\mathrm{e}}$ eeuw ook in Delft en Dordt hun stillen, doch vruchtbaren arbeid verrichtten, hebben getracht, de herinnering vast te houden; van Bleiswijk vertelt van het West-Indische huis, dat in zijn tijd op de Geer stond, zoodat het artilleriemagazijn van Holland aan beide zijden uitzag op Iudische kantoren. Boitet vermeldt (in 1729) dit gebouw ook nog, maar het is dan reeds lang verlaten en ingericht voor plateelbakkerij terwijl de bewindhebbers niet anders meer hebben dan "een vergaderkamer ten huyze van hunnen kommys op het marktveld". Evenzoo heeft de ijverige Balen niet verzuimd, te Dordrecht een enkel woord an het West-Indische huis te wijden.

Maar de boeken dezer ijverige werkers zijn helaas zoodanig ingericht, dat zij meer voor naslaan dan voor doorlezen geschikt zijn. Daarom ziju hunne aanwijzingen omtrent de W. I. C. vrijwel zouder uitwerking gebleven, want hij, die iets zocht over deze maatschappij, kwam niet te Delft of te Dordt, en hij, die studiën ging maken van Dordt of Delft, dacht niet aan de West-Indische Compagnie. Schrijver dezes zou zeker ook geen uitzondering op dezen regel gemaakt hebben, indien hij niet verplicht ware geweest, in 't Rotterdamsch archief naar stukken over 't West-Indische huis aldaar te zoeken; hier vond hij een spoor, dat hem al spoedig naar Delft leidde, terwijl een ander naar Dordt wees.

Toen eenmal de aanduiding gevonden was, moest de verzuchting

1 J. Franklin Jameson, Willem Usselinx, New-York 1887, blz. 33. 
van 't hart: eigenlijk hadden we dat toch wel kunnen denken en daar wat eerder zoeken!

Waar de West-Indische Compagnie feitelijk opgericht is van staatswege en niet anders dan met inspanning van alle regeeringskrachten haar beslag heeft kunnen krijgen, kon men immers moeielijk verzuimen, steden als het rijke Dordt en het aauzieulijke Delft er mee in te halen. Bij de Merwe-stad zou hoogstens nog als bezwaar hebben kunnen wegen het feit, dat ze niet meegedaan had aan den handel op Oost-Indië, 1 bij Delft was er niets van dien aard te bedenken.

Delft, de vriendelijke, bekoorlijke stad der lichtgebogen lijnen, had in 't gebied der Maas altijd mee vooraan gestaan. In den roemrijken opstand tegen Spanje had het een schoone rol gespeeld, wijkplaats eerst voor Prins Willem en de Staten, later ook nog voor Oldenbarneveldt en Maurits! Zijne ligging zoo dioht bij den Haag, die in onze dagen door menig Delftenaar beklangd wordt, was toen van groot voorleel geweest, terwijl de nabijheid der Maas aan de andere zijde nog de gelcgenheid had geboden, een haven voor zeeschepeu te bezitten. Daar had, naast de koopvaardij, vooral de haringvisscherij gebloeid, zoodat de stad Delft al spoedig was opgetreden onder de zetels der Groote Visscherij en dat zelfs de vergaderingen van de Gedeputecrden ter haringvangst altijd op 't stadhuis of den Doelen van Delft werden gehouden. Toen de manhafte tochten naar het verre Oosten begonnen waren, had deze stad daaraan dan ook even goed deelgenomen als Rotterdam, ja veel meer zelfs; bij het oprichten der Vereenigde Oost-Indische Compagnie bezat ten minste de kamer van Delft bijna driemaal zooveel kapitaal als de Rotterdamsche.

Wel is waar had Delft met zijn haven vrijwat getobd en gesukkeld èn door de woede der Spanjaarden èn door de "precysheit" van 't eigen stadsbestuur, dat altijd vreesde, den Piraeus aan de Maas te zien groeien boven het Athenc in den polder, maar daartegenover was het weinig geteisterd door de Arminiannsche beroeringen. Toen dau ook, in 1621, de Engelsche MerchantAdventurers hun factorij van Zeeland naar Holland gingen verplaatsen, kozen ze uit de Maassteden niet Rotterdam, maar Delft. "Rotterdam", zoo beweerden ze, "leverde bezwaren op, wegens Arminianen en garnizoenen"; bewijs genoeg, dat Delft dit geluk

1 Ofschoon Dordt toch nog wel enkele pogingen gedaan had, om er deel aan te krijgen. 
te danken had aan zijne kalme houding in den partijstrijd, maar buitendien ook aan zijue veilige ligging en aan de goede kansen, die het als stapelplaats bood.

Van het eerste oogenblik af, mogen we zeggen, dat door Willem Usseliux het plan eener West-Indische maatschappij was opgeworpen, was dan ook aan Delft gedacht, meer nog dan aan Rotterdam en aan Dordt; de gezamenlijke Maassteden hebben den ondernemenden Vlaming steeds voor oogen gestaan, al was 't eerst in de derde plats; hij meende zelfs, in zijne zucht, om overal de belangstelling voor zijne Compagnie wakker te roepen, dat Schiedam en den Briel mede in aanmerking mochten komen.

En later, bij den aanvang der walvischvangst aan de kusten van Spitsbergen c. a. had Delft zelfs de tweede plaats ingenomen in de Noordsche Compagnie, ver boven Rotterdam.

Al hebben nu de Staten-Generaal ten slotte de voorstellen van Usselinx niet in allen deele overgenomen, ten opzichte der propaganda schijnen ze er toch niet ver van te zijn afgeweken. Ze bleven trouwens nog tot in 1622, toen het octrooi al lang verleend was, met Usseliux in onderhandeling en wilde hem b. v. gebruiken, om kapitaal te zoeken voor de nieuwe onderneming. - Intusschen schreven ze zelf brieven naar links en naar rechts, om de magistraten en de gerechtshoven en in de steden aan te sporen, dat ze "met courageuse en liberale toekeuning de ingezetenen zouden voorgann." En ofschoon we niet met volkomen zekerheid kunnen zeggen, welke de hier bedoelde steden waren, zoo staat het toch wel vast, dat Dordrecht, Delft en Rotterdam werden behouden. Toen dau ook, op aandringen der Staten van Holland, op vele plaatsen commissies van directeuren benoemd werden, tot het bijeenbrengen der benoodigde kapitalen, bleef Rotterdam niet achter, doch Dordt en Delft evenmin.

't Is waar, dat die commissies in de twee laatstgenoemde steden moeite gehad hebben, om geld te krijgen, maar dat was overal het geval. Zelfs te Amsterdam moesten de directeuren lateu aanplakken, dat de inschrijving opengesteld werd voor iedereen van binnen en van buiten: "princen, heeren, republieken, edele en particuliere personen, zoowel binnen- als buitenslands". 1 Zeker een ongewone manier in die dagen. Wat Rotterdam betreft, dit heeft zóó geweldig te tobben gehad, dat het inleggers uit Utrecht, Arnhem en den Haag op de lijmroede ging vangen met beloften van bewindhebberschap

1 Zie Van Rees, Gesch. der Staathuishoudkunde. II. p. 129. 
voor 't leven, ja zelfs bij erfelijkheid! En met al die moeite, met al dat kunst- en vliegwerk schijnt het toch nauwelijks meer dan 2 ton bijeen gekregen te hebben '.

Dordrecht makte aan de Maas verreweg het beste figuur: de kapitalisten aldaar wilden blijkbaar het verzuim inhalen, begaan l,ij de Oost-Indische compagnie; zonder dat van vreemde inleggers gesproken was, hadden de Dortsche directeuren reeds 4 ton, toen Rotterdam nog niet aan zijn 2 ton was.

Te Delft wilde de zaak daarentegen zóc weinig vlotten, dat nog in 't begin van 1623 te Rotterdam in de vroedschap meegedeeld werd: "Delft heeft geen kamer geformeerd" ${ }^{2}$ en dat Dordt zich kort daarop aangordde, om "de portie van Delft" mede binnen zijne muren te trekken ${ }^{3}$.

Of misschien de aanzienlijke sommen, in de Oost-Indische en de Noordsche Compagnie gestoken, de Delftsche geldmannen hebben teruggehouden, dan wel, of de groote opofferingen bij de komst der Engelsche Court in den weg gezeten hebben, is niet goed uit te maken. Zeker is het intusschen, dat de toestand na de Meimaand van 1623 spoedig veranderd is. Toen op 3 Augustus van datzelfde jaar de eerste vergadering der Negentienen te Amsterdam bijeenkwam, was daar cen Delvenaar aanwezig, namelijk Adriaan van der Goes, vertegenwoordiger van de kamer van Delft, ja zelfs op dien dag éénig vertegenwoordiger van de gansche Maze ${ }^{4}$. En toen 't er op aankwam, volgens artikel 2 van den beschrijvingsbrief, opgave te doen van de ingeteekende kapitalen, bleef deze Delvenaar niet achter, al moeten we tot ouzen spijt bekennen, dat zijne cijfers voor ous verborgen ziju gebleven, evenals die van zijne collega's ${ }^{5}$. Zelfs bleek hij in de gelegenheid te ziju, bij de vrang naar de reeds gestorte gelden, het woord te voeren voor Dordt, dat al 60 of 70000 gulden in kas had gekregen en daarvoor een uitzending op de kust van Guinea gedaan had. Hierbij moest hij evenwel

1 Zie Rott. vroedschapsresolutiën, 25 Jan. 1623.

2 Zie Rott. rroedschapsresolutiën, 20 April 1624.

3 Idem 3 Mei 1623. Van Rees overdrijft waar hij beweert, dat Dord, naijverig op Rotterdam, de geheele kamer op de Maas verlangde te hebben. Zie Gesch. der Staathuishoudkinde. II. p. 75.

4 Zie de Notulen der Negentienen, 24 Juli 1623 tot 24 Dec. 1624 op het Alg. Rijksarchief.

${ }^{5}$ Idem. vergadering van 3 Aug. Juist wanneer men verwacht de opgaaf. der kapitalen te vernemen, wordt men hier teleurgesteld door stippeltjes en verwijzing naar de voorste notulen, die - niet meer aanwezig zijn.

7• Volgr. IX. 
voor zijne eigen kamer erkennen, dat ze nog geen enkele storting ontvangen had, evenmin trouwens als die van Rotterdam.

Bewindhebber was van der Goes nog niet, doch den $1^{\text {en }}$ September 1623 werd hij door Burgemeesteren van Delft daartoe benoemd naast vier anderen, nl. den burgemeester Autonie van den Heuvel en de vroedschapsleden Hendrik van Hillegum, Jacob Maartensz. Hogenhoek en Gerrit Vockestaert. In October vinden we dan ook "bewindhebber" van der Goes in plaats van directeur van der Goes in de vergadering der Negentienen; naast hem zit nu echter een ander vertegen woordiger van "de Maze", een man vau grooter gaven en beroemder naam: Jacob de Witt van Dordt. ${ }^{1}$

En het spreekt vanzelf, dat deze nu het woord voert voor Dordt, Delft en Rotterdam samen, die immers in deze vergadering altijd voor één lichanm gerekend bleven. Aangezien hij nu evenwel begonnen is met zeer uitvoerige vertogen over een kwestie van vertegenwoordiging, duurt het nog lang, vóórdat we iets naders over de beteekenis der Delftsche Kamer op zichzelve vernemen. Jacob de Witt heeft namelijk al dadelijk met kracht van redenen eu zelfs met dreigen en dringen voorgesteld, aan "de Maze" drie in plaats van twee vertegenwoordigers in de Kamer der Negentienen te geven, niet ten behoeve van grooteren invloed, maar enkel, om beter op de hoogte te blijven: de drie afgevaardigden zouden tevreden zijn met de twee door 't octrooi toegekende stemmen; ze verlangden alleen, met zijn drieën de vergaderingen bij te wouen, juist, omdat ze ieder voor een eigen lichaam zouden opkomen, namelijk voor de Kamers, of, als men wilde, onderafdeelingen, van Dordt, Delft en Rotterdam.

Nadat de Witt over deze kwestie verscheidene malen gesproken heeft en meer dan eens met twee collega's van Delft en Rotterdam in de vergadering verschenen, doch er weer uitgezet is, heeft hij den strijd moeten opgeven: den $25^{\text {en }}$ Maart 1624 werd beslist, dat men zich zou houden aan twee vertegenwoordigers van de Maze en meer niet. De drie heeren, die annwezig waren, moesten nu zelf maar kiezen, wie er zouden blijven. Nadat ze met zijn drieën eenige oogenblikken "buytengestann" hadden, zag men de Witt weer binnenstappen met den Rotterdammer van der Veen; de Delftenaar was dus uitgevallen voor het oogenblik. ${ }^{2}$

${ }^{1}$ In de vroegere vergaderingen is wel als lid der Negentienen genoemd Dirk Pz. van der Veen van Rotterdam, doch alleen als "absent".

2 Zie de notulen van de Negentienen, 25 Maart 1624. 
Hiermee was echter de fiere Jacob de Witt nog niet uit het veld geslagen: hij kwam den $26^{\text {en }}$ Maart reeds wederom met andere eischen, bij gelegenheid, dat men nog eens weer over de opgave der ingeteekende kapitalen te spreken had.

De Dordtsche burgemeester deelde toen mede - zonder de geheimhouding in de secrete notulen te verlangen - dat Dordt zich wilde verbinden tot een kapitaal van een half millioen, mits het dan ook voor zich alleen een tiendepart van de geheele equipage zou krijgen en gelijk gezag in de directie als de andere kamers. ${ }^{1}$

Tevens gaf hij te kennen, dat te Delft reeds voor 3 ton was ingeteekend, doch dat men daar eveneens zijn eigen verlangens had, namelijk "equipage naar advenant van den inleg." ${ }^{2}$

Hier vinden we dus voor 't eerst een opgave van het Delftsche kapitaal, een opgave, die zeker den Rotterdamschen afgevaardigde van der Veen niet aangenaam in de ooren zal geklonken hebben, want ze was ruim de helft hooger dan degene, die hijzelf te doen had. Hij kon zich eu zijne committenten alleen troosten met de gedachte, dat Delft ook al evengoed hulp buiten zijne muren had moeten zoeken als Rotterdam, maar in zijne binnenkameren zal hij toch ook in dit opzicht tot de erkentenis hebben moeten komen, dat zijn eigen stad niet het beste figuur maakte van de twee. Uit geen van de Delftsche berichten blijkt namelijk, dat daar Geldersche, Utrechtsche of andere deelhebbers zijn binnengesleept met levenslange bewindhebbersrechten of dergelijke lokmiddelen. Alleen Hagenaars vinden we vermeld en wel in zoo grooten getale, dat in de residentie een onderafdeeling van de Delftsche Kamer is gesticht, die later den naam van "Haagsche societeit" verkreeg. Men moet hierbij intusschen geenszins denken aan eene filiale met eigen handel en uitrusting, doch alleen aan een afzonderlijk lichaam van hoofdaandeelhouders, dat twee bewindhebbersplaatsen hielp vervullen in de Delftsche Kamer. ${ }^{3}$

1 Notulen der Negentienen, 26 Maart 1624.

2 De Delftenaren hebben dus eene soort trustformatie voor den geest gehad, die echter niet in de bedoeling van het octrooi der W.I. C. lag (zie de zeer interessante dissertatie van Mr. E. J. J. van der Heyden over ${ }_{\text {de }}$ ontwikkeling der naaml. vennootschap in Nederland", blz. 90).

3 De Haagsche hoofdparticipanten maakten namelijk twee voordrachten; uit de eene koos het Hof van Holland tezamen met de regeering van den Haag, uit de andere kozen de gezamenlijke hoofdparticipanten van Delft en den Haag, zoodat de benoeming aan ingewikkeldheid niets te wenschen liet. 
Aangezien uu de hoofdparticipanten te Delft zelf de voordrachteu opmaakten voor vijf bewindhebbers (te kiezen door Burgemeesteren), kan men gerust aannemen, dat binnen de Stad Delft alleen wel twee derde vau het kapital der gansche kamer zal ingeteekend zijn, dus op zichzelf al meer dan in de gehcele Kamer van Rotterdam. Dit wordt nog waarschijnlijker, als men ziet, dat den $27^{\mathrm{n}}$ Maart 1624 Jacob de Witt nogmaals het woord neemt en verklaart, dat Delft zelfs boven de drie ton zal inschrijven.

We komen dus, voor zoover dwars door de nevelen der geheimzinnigheid is waar te nemen, tot de verrassende conclusie, dat Rotterdam allerminst de zetel, ja niet eens de hoofdzetel der Kamer van de Maze geweest is: het heeft in den beginne, wat kapitaal betreft èn bij Dordt in bij Delft achtergestaan.

Natuurlijk hebben de Rotterdammers, volgens de gewoonte van jong-opkomende menschengroepen, door vermetelheid (of, als men wil, brutaal optreden) trachten te vergoeden, wat ze aan bezit ten achter waren; - dit is hun ook werkelijk gelukt, in zooverre, dat, na vele disputen, het bedrijf, voor de Maze bestemd, gelijkelijk verdeeld is tusschen de drie steden, die dus ieder welgeteld $\frac{1}{27}$ deel kregen van den handel en de uitrustingen der Geoctroycerde West-Indische Compagnie ${ }^{1}$.

Indien het nu war is - wat door Luzac, Laspeyres en van Rees eenstemmig beweerd wordt, maar door ons nergens in de bronnen aangetroffen is - dat de geheele eerste inschrijving ruim 7 millioen gulden bedragen heeft, dan is dus aan Rotterdam 50 pCt. te veel toegekend, want zijn kapital bedroeg slechts $\frac{1}{36}$ deel van 't geheel. - Delft daarentegen heeft iets te weinig ontvangen: $\frac{1}{27}$ in plaats van $\frac{1}{2} \overline{4}$, maar Dordt is er, in spijt van zijn hoogen rang onder de steden en van zijn scherpziunigen afgezant bij de Negentienen, bijzonder kaal afgekomen; het had bijna $\frac{1}{14}$ deel van 't kapitaal en kreeg maar ruim half zoo veel vau het bedrijf!

Hieruit volgt meteen, dat de Maze als geheel genomen eenigszins stiefmoederlijk behandeld is: dit komt nog te beter uit, als men verneemt, dat de Kamer van Hollands Noorderkwartier (Hoorn en Enkhuizen) slechts een half millioen in de eerste inteekening wist

1 Dit is door de steden onderling uitgemaakt, buiten medewerking der Negentienen, in denzelfden tijd, dat ook de drie Zeeuwsche plaatsen Middelburg, Vlissingen en Veere hun contract sloten, waarbij de verdeeling echter niet gelijkmatig uitviel (zie van Brakel „Ned. Handelscomp. der $17 \mathrm{e}$ eeuw", 143). 
te verkrijgen ${ }^{1}$ en toch haar $\frac{1}{9}$ deel van 't bedrijf behield; wellicht als schadeloosstelling voor het bekende verlies van de zoutvaart.

Vraagt men nu, of Delft en Dordt, op eenigerlei wijze een dergelijke achterstelling verdienden, dan meenen we dit ronduit te moeten ontkennen: men is er ijveriger met zijne stortingen, dus ook met zijne uitrustingen, geweest dan in het Noorderkwartier, dan in Zeeland, ja zelfs dan te Amsterdam.

Over de diensten, door de West-Indische Compagnie in 't algemcen es door de kamers van de Maze in 't bijzonder bewezen aan de militaire en commercieele belangen des lands, zullen we hier natuurlijk niet uitweiden; alleen willen we even den beroemden "Havenaar" Piet Heyn aauhalen, om er op te wijzen, hoeveel natuurlijker en eenvoudiger zijn leven past in het kader der Compagnie, wanneer men weet, dat zijn eigen vaderstad Delft een afdeeling daarvan bezeten heeft. Had hij te Rotterdam of elders in dienst moeten treden, dan zou hij zeker als "vreemdeling" lang niet zoo snel zijn opgeklommen. Wonderlijk, dat zelfs ziju gevierde naam zijn eigen stedelijke kamer niet voor vergetelheid heeft kunnen bewaren!

Op zuiver commercieel terrein zou er trouwens niet eens veel te vinden zijn omtrent het bedrijf der Compagnie, daar ze immers den handel steeds op den achtergrond gehouden heeft. Reeds in 1631 - ziehier een feit van beteekenis - stelde zij uit eigen beweging de vaart op de meeste Amerikansche gewesten open voor iederen Nederlandschen koopman, tegen betaling van een zeker vergunningsrecht.

't Is de moeite waard, te vermelden, dat de kamers van Dordt, Delft en Rotterdam zich éénstemmig hier vóór verklaard hebben, natuurlijk op uitdrukkelijke voorwarde, dat ieder ook van de voordeelen dier particuliere vaart precics zijn deel zou krijgen. Men behoeft niet te vragen, of dit aanleiding kon geven tot moeilijkheden in 't gebied van de Maze.

Aan kwesties van allerlei aard was buitendieu van 't begin af an geen gebrek geweest, doch ze werden steeds erger, vooral toen tegen 't einde van den Spaanschen oorlog de beste inkomsten kwamen te vervallen.

Er is dan ook omstreeks dien tijd, namelijk bij den afloop van het eerste octrooi (1646) reeds sprake geweest van opheffing of wel van samensmelting met de Oost-Indische Compagnie, maar zoowel 't een als het ander is verhinderd (alweer met medewerking der Maassteden)

1 Zie Notulen der Negentienen van 18 Sept. 1624. 
en er is opnieuw octrooi verleend op dezelfde voorwaarden en voor denzelfden tijd van 25 jaar, terwijl de rijkere zuster, de Oost-Indische Compagnie, niet minder dan een millioen gulden aan de West-Indische moest ten geschenke geven. Niettegenstande deze aaumerkelijke fooi 1 stond deze laatste toch in 1651 zóó slecht, dat op de Groote Vergadering zeer ernstig over haar toestand gehandeld werd. Mag men een der meest verspreide pamfletten uit dien tijd gelooven, het "Vertoogh over den toestant der W. I. C. in haer begin, midden ende eynde met een Remedie tot redres van deselve", dan was reeds sedert 1649 het groote kwaad gezocht in den geweldigen bedrijfsomslag, het "veelhoofdig bestuur". En dat met alle recht (afgezien natuurlijk van den oorlog); - immers bij elke beschouwing, ook bij de onderhavige, blijkt meer en meer, dat het bedrijf buitengewoon verspreid was, erger nog dan bij de Oost-Indische Compagnie: slechts twee ongedeelde kamcrs, Amsterdam en Grouingen daarnaast twee afdeelingen in Noord-Holland, drie aan de Maas en drie in Zeeland; alles tezamen tien kantoren, ieder met eigen uitrusting, eigen handelsbedrijf, eigen bestuur en personeel!

Stel u voor, dat de drie afdeelingen aan de Maze alleen elk een getal van 6 of 7 bewindhebbers bezaten: twintig directeuren, om met een kapital van één millioen gulden te werken!

Eeu zeer radical plan tot vereenvoudiging moet, volgens het bovengenoemd pamflet, al vau $1649-51$ in de Staten-Generaal in bespreking geweest zijn: afschaffing van alle bewindhebbers en vervanging door een central bestuur in den Haag, een Rekenkamer van zeven leden, afdanking van alle ambtenaren eu beambten, behalve eenige equipage-meesters in de kamers met de meeste uitzending. Ja zelfs moet er sprake van gewcest zijn, ook die niet te behouden, doch de uitrusting eenvoudig aan de admiraliteiten over te laten. Was dit laatste uitgevoerd, dan zou eigenlijk toen reeds het gansche beheer over de West-Indische zaken in handen van den Strat gekomen zijn; van de Compagnic zou niets overgebleven zijn dan de andeelhouders met hun kapitaal, indien ze teuminste geneigd waren geweest, dit op deze wijze in handen der overheid te geven. In elk geval zou Delft zijn West-Indisch huis wel verloren hebben, want het behoorde zeker niet tot de kamers met de meeste uitreeding. De Groote Vergadering was er intusschen niet naar gestemd, om zulke principiëele veranderingen door te zetten; haar president Jacob Cats

1 Een fooi in zooverre, dat de W.I. C. bij haar zwaren strijd om octrooiverlenging hiermee voorvechters won. 
zal zeker wel in den geest harer meerderheid gesproken hebben, toen hij verklaarde, dat de Oost- en West-Indische Compagnieën, als zijnde "de beide pilaren van den Staat", moesten gehandhaafd blijven. Ook zou het niet bijzonder eervol geweest zijn, indien men in 1651 een van deze twee op de pas vermelde wijze tersluiks had trachten op zij te zetten, terwijl vijf jaren tevoren haar octrooi voor een kwarteeuw op den ouden voet verlengd was. Het resultaat van de bespreking was dan ook, dat de Groote Vergadering aan de inrichting der Compagnie niets veranderde, maar enkel vereenvoudiging zocht in vermindering van de bewindhebbers tot op de helft. ${ }^{1}$ Zoo bleef dus ook de Delftsche kamer bestaan, maar ze behield slechts drie directeuren, 't geen zeker nòg genoeg was: twee uit Delft en één uit den Haag. Voor Delft zelf was er weinig hoofdbrekens noodig, om uit te maken, wie die twee gelukkigen zouden zijn, want men had reeds tevoren een paar vacatures opengelaten, zoodat er niemand behoefde te worden afgedaukt. ${ }^{2}$ Van de Hagenaars moest echter de heer Willem Schadé uitvallen, zoodat alleen de bewindhebber overbleef, die door het Hof van Holland op voordracht der Hoofdparticipanten gekozen was.

Deze inkrimping beteekeude voor de Kamer van Delft een jaarlijksche bezuiniging van f $2226-17$ st., daar ieder bewindhebber een tractement genoot van f 742-5 st. en 10 p. Bovendien werd ook nog het salaris van 't kantoorpersoneel verminderd, 'tgeen zeker wel méér last en verdriet zal bezorgd hebben: de boekhouder kwam van f 600 op f 500 en de equipage-meester moest van zijn povere f 400 zelfs f 150 missen (terwijl hij intusschen onverkort zijn vrije woning

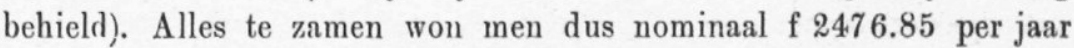
uit, maar de toestanden der laatste jaren in aanmerking genomen, bedroeg de winst in werkelijkheid nog geen 1000 gulden (daar immers de twee bewindhebbers-vacaturen reeds eenigen tijd bestonden).

Veel verlichting kon dus het besluit der Groote Vergadering hier niet geven en wanneer het elders op dergelijke wijze gegaan is 't geen ons op 't oogenblik niet bekend is $-{ }^{3}$ dan heeft het jaar

1 Volgens de reeds vermelde authentieke memorie in het Delftsche archief, waaruit ook het volgende geput is, nam de Groote Vergadering dat besluit op 11 April 1651.

${ }^{2}$ De twee bewindhebbers waren tôen Joost van Lodensteyn en Arent van der Graaff.

${ }^{3}$ De opgaven voor Delft zijn ontleend aan een "Extract uit de Resolutiën van Bewindhebbers der W. I. C. ter Camere binnen Delft", bewaard gebleven op het gemeentelijk arehief aldaar. 
1651 voor de Compagnie al even weinig verbetering gebracht als voor 't land zelf.

De volgende jaren waren echter - gelijk algemeen bekend is nog veel slechter: de oorlogen met Engeland en de Portugeesche aanvallen in Brazilië beroofden de Compagnie van hare voornaamste bezitting en brachten haar financiecl geheel in het verderf. Had ze vroeger reden gehad, den oorlog en de kaperij te prijzen, nu vond zij gelegenheid, om de $\mathrm{kwade}$ zijde daarvan te leeren kennen.

Deze stormen brachten te weeg, wat de Groote Vergadering niet gekund of gedurfd had: aan de Maze werden eindelijk de drie kleine kamers. gecombineerd. Den $20^{\text {en }}$ December 1669 , dus nog vóórdat het tweede octrooi ten einde liep, werd besloten, dat de kantoren te Dorlt en te Delft zouden worden opgeheven. ' Te Rotterdam op het Haringvliet zou voortann het eenige kantoor van "de Maze" gevestigd zijn. Toch werd de toestand nog niet dadelijk zoo eenvoudig als men uit deze hoofdbepalingen zou opmaken; niet alleen, dat te Dordt drie directeuren zouden gevestigd blijven, te Delft twee en in den Haag één, maar ook zouden al deze plaatsen nog iets van den handel en (zooveel mogelijk) vau de scheepvaart moeten blijven genieten. Voor inkoopen van handelswaren, equipage-artikelen, ammunitie, vivres, enz. moesten alle vier steden begunstigd worden, terwijl de equipages met eigen of gehuurle schepen van drie tot drie jaar geschieden zouden te Dordt, Delfshaven en Rotterdam en de veilingen der retourwaren insgelijks om de beurt zouden plaats hebben, daar de steden van uitvaart altijd bij de thuisreis weer moesten opgezocht worden. Allcen was uitdrukkelijk voorgeschreven, dat de verkooppenningen in elk geval naar Rotterdam moesten gebracht worden, in de "generale cassa van den Heer ontvanger van de Maze".

Hoe noode toch de twee "groote" steden Dordt en Delft van hunue oude illusies afstand konden doen! Zij hadden eeumaal een behoorlijk aaudeel genomen in de Compagnie, alleen om wat handelsdrukte in hunne vesten te krijgen, - nu moest en zou dat bedrijf er ook blijven, al was 't er niet goed meer op zijne plaats.

Rotterdam met zijn gunstiger positie mocht het centrale kantoor met de algemeene kas hebben, van de scheepvaart en den handel moest ieder zijn deel bchouden.

Is dan, zoo zal men geneigd zijn te vragen, dat verdrag van

1 Zie het bovengenoemde „Extract". 
1669 niet in hoofdzaak weer een schijnhervorming geweest evenals het bovengenoemde besluit der Groote Vergadering? Is er bv. te Delft wel iets anders gebeurd dan een degradeering van den boekhouder tot "commies" en een nieuwe beknibbeling op het schamel traktement van den equipagemeester? Maakte het voor Delft in de praktijk wel eenig verschil, of de geldelijke opbrengst der verkoopingen naar Rotterdam ging, wanneer toch de winsten hun weg vonden naar de plaatsen, waar de aandeelhouders woonden?

De winsten? Wie dacht hier nog aan winsten? Verliezen waren immers sedert jaren regel geworden en, dit in aanmerking genomen, mocht het verdwijnen der bijzondere kas uit Delft eer een opluchting dan een oorzaak van verdriet heeten! Wil men opmerken, dat het toch wel verandering mocht genoemd worden, wanneer voortaan te Delft slechts drie van elke negen jaren iets van West-Indisch bedrijf was te bemerken, dan stond daar tegenover, dat Rotterdam en Dordt toch ook maar een zelfde triennium van verkoopingen en uitrustingen der Maatschappij meer kenden.

En evenwel was de verandering van 1669 niet gering. De hoofdzaak zat in artikel 6 van de overeenkomst, waarbij bepaald werd, dat de particuliere schepen, die op recognitie aan de Compagnie voeren, voortaan konden gaan en komen waar ze wilden, mits de recognitie betalend aan den Ontvanger-Generaal te Rotterdam.

Het ligt voor de hand, vooral door de laatste bijvoeging, dat deze vaartuigen nu in den regel ook te Rotterdam gingen lossen en laden en dit beteekende niet minder, dan dat de eigenlijke handel op Amerika voortann de havens van Delft en Dordt ging mijden. Immers, de Compagnie zelf, die trouwens nooit erg commerciëel van aanleg was geweest, had dien handel reeds lang bijna geheel aan het initiatief der bijzondere kooplui overgelaten. 1 - Waar nu nog expresselijk an artikel 6 toegevoegd was, dat ook de vreemde schepen, die direct uit Barbados, Virginia, Nieuw-Engeland, enz. ankwamen, mede onder de nieuwe voorwaarden werden gebracht, kon het wel niet anders, of de suiker, indigo en cacao van WestIndië en de tabak van Noord-Amerika moesten voortaan aan de Maas geen andere haven opzoeken dan de Rotterdamsche. - Zoo wordt het begrijpelijk, dat de negen bewindhebbers, wanneer ze den eersten Maandag van elke maand bijeenkwamen in het Rotterdamsch West-Indisch huis, "als zijnde zeer wel gelegen en daartoe

1 Behalve den koop en verkoop van slaven, die echter uit den aard der zaak in de Nederlandsche havens weinig te bemerken was. 
best en bequaemst geoordeelt" , ook in de zes jaren van stilstand nog wel wat anders te zien kregen dan het incasseeren der veilgelden uit Delft en Dordt; - regelmatig, jaar in jaar uit toch had de boekhouder-generaal met zijn kassier en zijn klerk werk met de in- en uitklaring der particuliere Transatlantische schepen.

Indien het doel van Delft en Dordt met hun pas vermelde opoffering geweest is, het octrooi der Compagnie in 1671 opnieuw verlengd te krijgen, dan zijụ ze hierin teleurgesteld. De StatenGeueraal gevoelden geen lust, om de Republiek nog lnnger op dezen vervallen pilaar "te doen rusten"; ze lieten hem los en dadelijk daarop kwam de ontzettende oorlog van 1672 , die hem geheel omverwierp. - Toch werd, na den vrede van 1674, uit het halfvermolmde hout nog weer een nieuwe stut gefabriceerd; de Tweede West-Indische Compagnie verkreeg op den $20^{\mathrm{n}}$ September van dat jaar een octrooi, dat wel begon met de formule: "de nieuwe Compagnie heeft met de oude en nu gedissolveerde geen gemeenschap en is niet aansprakelijk voor hare schulden", maar dat toch in alle opzichten een reconstructie bevatte. - Dezelfde aandeelhouders, dezelfde obligatiehouders, dezelfde kamers, ja dezelfde onderafdeelingen, al bestouden de laatste ook hier en daar slechts in naam meer. Het eenige verschil met de vroegere Compagnie zat hierin, dat de obligatieschulden meer dan getierceerd werden en dat de aandeelhouders slechts $15 \%$ van hun inleg meer erkend zagen (nòg cen buitenkausje, waar ze feitelijk met het volle bedrag aansprakelijk geweest waren in dezen radicaal faillieten boedel). - - Daar de obligatiehouders hun $30 \%$ in aandeelen uitgekeerd kregen, genoten ze voortan het voorrecht, ook participanten te heeten, zoodat het aantal daarvan zelfs nog grooter werd dan voorheen. Ook moesten ze, volgens het nieuwe voorschrift, $8 \%$ op hun kapitaal bijstorten, om de maatschappij aan gereed geld te helpen (terwijl de oude aandeelhouders met $4 \%$ konden volstann).

Als gewichtige nieuwigheid werd nog angekondigd, dat het alleenhandelsgebied voortaan slechts zou omvatteu "de kusten vau Afrika van den kreeftskeerkring af tot op dertig graden bezuiden de evennachtslijn en alle de tusschen beide gelegen eilanden, alsmede Essequibo en andere plaatsen aan de kust van Amerika gelegen, en bijzonderlijk het eiland Curaçao". ${ }^{1}$ Daar evenwel voor al het

1 Tegenw. Staat der Vereen. Ned. Deel I. p. 521 vlg. 
overige territoir vau de oule Compagnie het recht van retributieheffing bleef bestaan, beteekende dit al evenmin een groote verandering als de meeste andere artikelen van dit tweeslachtige regeeringsbesluit. Zelfs de bepaling, dat van nu ann de handel hoofddoel, ja zoo goed als het eenige doel zou wezen, heeft weinig nieuw leven gebracht, want vooreerst was het met het militair optreden der Compagnie al lang droevig gesteld geweest en ten tweede heeft ze ook in haar beperkt monopolie-terrein al spoedig weer particulieren toegelaten. Noch voor het anzien noch voor de welvaart van den Stant is de reconstructie van 1674 een gelukkige maatregel geweest.

Of nu bij de bezittingen, die, op taxatie aan de nieuwe Compagnie overgingen, ook nog het West-Indische huis op de Geer te Delft geweest is, kunnen wij niet met zekerheid zeggen. 't Is mogelijk, dat de bewindhebbers het reeds in 1669 , bij de samensmelting der drie kamers op de Maze, verkocht hebben volgens artikel 7 van de toen gesloten overeenkomst, dat afschaffing van "alle onnutte huyzingen, wooningen, mitsgaders boekhouders, equipagemeesters en andere suppoosten van de drie leden" voorschreef. Zoo niet, dan heeft de nieuwe Compagnie het gebouw toch al spoedig van de hand gedaan: in de dagen van Boitet, die zijn geschiedkundige beschrijving in 1729 uitgaf, was het reeds lang herschapen in een platteelbakkerij; ${ }^{1}$ wanneer de Delftsche bewindhebbers nog iets te vergaderen hadden, b.v. bij 't vervullen van vacatures, dan kwamen ze bijeen in "een bequame kamer ten huyze van hunnen commys op het Marktveld, aan de zijde der Voldersgracht. ${ }^{2}$ Zoo was dus de Delftsche afdeeling, die vroeger de Rotterdamsche in aanzien en kapitaal overtroffen had, nu teruggebracht tot een "kamer in letterlijken zin, zóó klein en onbeduidend, dat hare vergaderplaats zelfs bij de Delftsche oudheidkundigen in vergetelheid geraakt is. ${ }^{3}$ Aanteekeningen omtrent haar bestaan zijn nog bewaard gebleven over verscheidene jaren van de $18^{\mathrm{e}}$ eeuw tot 1759 toe. Ze bevatten evenwel weinig anders dan benoemingen van bewindhebbers en menigvuldige kleine kwesties over rangorde in vergaderingen, over inkoopen en uitrustingen, opvolging van directeuren, enz.,

1 Zie aldaar blz. 564 .

2 Gedrukte oproepingen aan bewindhebbers en hoofdparticipanten zijn nog in het Delftsche gemeentearchief aanwezig, en spreken van het huis op de Voldersgracht.

3 De juiste plaats zal trouwens moeielijk terug te vinden zijn. 
die de moeite van het opsommen niet waard zijn. ${ }^{1} \mathrm{Er}$ is geen reden om an te nemen, dat dit na 1759 anders geworden is, zoodat we gerust kunnen gelooven, dat de Delftsche "kamer" haar schijnbestan nog heeft voortgesleept tot aan den ondergang der Compagnie in 1791.

De gansche geschiedenis van de deelneming der bekoorlijke Prinsenstad in de West-Indische Maatschappij geeft een vrij helder beeld van haar geheele optreden in do groote overzeesche ondernemingen. Van het jaar 1600 af, toen de nieuwe sluis te Delfshaven een behoorlijken toegang naar Delft verzekerde (in plaats van de vroegere nauwe duikersluis) hadden de regeerders en de burgerij der stad met ijver (ofschoon niet zonder de "preciesheid", die Oldenbarneveldt gelaakt heeft) getracht, den groothandel te lokken. Achtereenvolgens hadden ze deelgenomen aan de vaart op Oost-Indie, de roemruchte tochten naar de IJszee, den grooten handel op Engeland. Midden in dit bloeitijdperk was de West-Indische Kamer opgericht en had haar veelbezongen goudregen mede in de stad van Piet Hein doen neerdalen. $\mathrm{Na}$ de dagen van Frederik Hendrik was het evenwel spoedig met de handelsgrootheid gedaan geweest, omdat men toch, met alle kunstmiddelen, Delft niet tot een echte zeehaven had kunnen maken. Alles hing hier aan papieren voorschriften.

Toen in 1635 de Engelsche Adventurers hun contract opzegden, wegens "gebrek aan retourwaren te Delft", verdween op eens alle Engelsche handel; toen de Noordsche Compagnie in 1644 haar octrooi verloor, zag Delft als cen vau de eersten zijn walvischvangst wegslinken, toen de West-Indische Compagnie ging kwijnen, kon Delft al spoedig heel weinig Amerikaansche vaart meer bespeuren. Alleen de Oost-Indische handel bleef nog zeer lang aan Delft getrouw in dezelfde mate als aan Rotterdam, maar - de winsten gingen op den duur naar Amsterdam en elders ${ }^{2}$, waar de aandeelen der Delftsche Kamer heen gedwaald waren, en de scheepvaartdrukte (der groote driemasters) kwam ten laatste niet verder dan Hellevoetsluis, daar de Delftsche haven door een booze plaat werd bedorven. ${ }^{3}$

1 Een moeielijkheid gaf 0 . a. het feit, dat er nu 7 bewindhebbers waren voorgeschreven, waarvan één de bijzondere gekozen vertegenwoordiger van de hoofdparticipanten was (die nu een georganiseerd lichaam vormden met president, vice-president, secretaris en rekenmeesters). Daardoor schoten er voor Rotterdam, Dordt en Delft ieder twee bewindhebbers over, maar kwam den Haag met zijn "societeyt" in 't gedrang.

2 Volgens het overdrachtsboek der actien van de Delftsche Kamer, dat nog in 't Algemeen Rijksarchief bewaard is.

3 Volgens de papieren van den Delftschen bewindhebber van Vredenburg in het Algemeen Rijksarchief. 